\title{
International Journal of Traditional and Complementary Medicine
} (IJTCM)

\section{Evaluation of ameliorative potential of isolated flavonol fractions from Thuja occidentalis in lung cancer cells and in Benzo(a)pyrene induced lung toxicity in mice}

\section{Avinaba Mukherjee ${ }^{1}$, Sourav Sikdar ${ }^{1}$ and Anisur Rahman Khuda-Bukhsh ${ }^{1^{*}}$}

${ }^{1}$ Cytogenetics and Molecular Biology Laboratory, Department of Zoology, University of Kalyani, Kalyani-741235, West Bengal, India.

\section{ABSTRACT}

Relative anticancer potentials of six flavonol fractions (F1-F6) isolated from Thuja occidentalis extract were first evaluated against lung cancer cells A549 in vitro, and fraction- F4 showing the maximum protective ability, was then tested in mice intoxicated with Benzo(a)pyrene (BaP), a known carcinogen with major effect on lung, to learn if this could also have ameliorative action against lung toxicity and tissue damage in mice in vivo. Chemical nature of F1-F6 fractions was confirmed with specific flavonol confirmatory test and mass spectral analysis; all fractions were tested for their possible anticancer effects against A549 cells. Results suggested that fraction 4 (F4) had the strongest anticancer effect. When treated to BaP intoxicated mice, F4 induced recovery of damaged lung tissue, presumably through inhibition of ROS generation, and enhanced production of major antioxidant molecules, that in turn blocked PI3K-activated expressions of Akt. Decrease in Bcl2/Bax ratio, over-expression of p53 gene and activation of caspase 3 were observed in tissues of F4 treated mice, further confirming apoptotic cell death as its major target. The F4 fraction of Thuja occidentalis extract showed remarkable apoptotic potential against lung cancer cells and ameliorative ability against BaP induced lung toxicity.

Keywords:

${ }^{*}$ Correspondence to Author: Anisur Rahman Khuda-Bukhsh Emeritus Professor

Email: prof_arkb@yahoo.co.in; khudabukhsh_48@rediffmail.com

Phone: +91-33-25828768 (O); +91$33-25828768(R)$.

\section{How to cite this article:}

Avinaba Mukherjee, Sourav Sikdar, Anisur Rahman Khuda-Bukhsh. Evaluation of ameliorative potential of isolated flavonol fractions from Thuja occidentalis in lung cancer cells and in Benzo(a)pyrene induced lung toxicity in mice. International Journal of Traditional and Complementary Medicine 2016;1(1): 0001-0013.

Accepted 28 June 2016; published July 72016.

Flavonol; benzo[a]pyrene toxicity; lung toxicity; PI3K/Akt pathway; reactive oxygen species (ROS), Thuja occidentalis 


\section{Introduction}

With rapid increase in the environmental toxic elements like polycyclic aromatic hydrocarbons (PAHs), lungs become primarily intoxicated, causing more incidence of lung cancer ${ }^{[1]}$. Among PAHs, Benzo(a) pyrene (BaP), which is found in cigarette smoke, coal tar, automobile fumes etc contributes heavily for developing non-small cell lung cancer (NSCLC $)^{[2,3]}$. BaP also remains in our daily foods ${ }^{[4]}$ in significantly high amount. It is readily absorbed and metabolized in the form of Benzo[a]pyren-7,8-dihydrodiol-9,10-epoxide that intercalates with $\mathrm{DNA}^{[5]}$. Through this method, it forms DNA adducts and facilitates DNA damage to induce lung cancer ${ }^{[6]}$. BaP, by altering normal oxidative threshold level via generation of free radicals like ROS can also distort lung tissue architecture ${ }^{[7]}$. Thus there is a need for target-specific chemopreventive agents which can combat BaP induced lung toxicity

Flavonols, are known to be promising chemopreventive phytochemicals, which have both nutritive value and target-specific anti-carcinogenic properties that help them combat cancer cells, but without causing much harm to normal cells ${ }^{[8,9]}$. Thus, plants having a rich source of flavonols are of interest for their possible chemotherapeutic use. Earlier reports have shown flavonol as a potential anticancer compound which helps in lowering the carcinogenesis process $^{[10,11]}$. However, the possible mechanism and pathway of action of flavonols against lung cancer are not yet fully understood.

Thuja occidentalis is an ornamental plant that grows in north-eastern areas of the United States and in the south east parts of Canada. It is known to contain (1.4-4) \% essential oils, flavonols, coumarins, tannic acid etc ${ }^{[12,13]}$. Earlier, we have shown that ethanolic leaf extract of Thuja occidentalis and isolated flavonols from it exert apoptotic effect on a kras mutated NSCLC cell line (A549) sparing the normal embryonic lung cell $(L-132)^{[14,15]}$, but further studies to isolate different flavonol fractions and identify if any particular flavonol fraction had greater anti-cancer potential against NSCLC cell line A549 or any particular fraction acted more strongly to ameliorate $\mathrm{BaP}$ induced lung toxicity are lacking.

Therefore, the hypotheses to be tested in this study were: i) If different flavonol-rich fractions could be isolated, identified and tested for their individual ability to induce cytotoxicity in lung cancer cells, A549 in vitro; ii) If any particular fragment could show greater ability to induce apoptosis, and whether this fragment could be effective in reducing $\mathrm{BaP}$ induced lung toxicity in the mice model as well, indicating its possible chemotherapeutic use; and iii) if the underlying mechanism of drug induced redox state modulation and the signal transduction, in particular, could be understood to know if it was mediated through the modulation of Akt signalling pathway, a major pathway involved in initiation of BaP induced toxicity as reported by earlier workers ${ }^{[16,17]}$.

\section{Materials and Methods}

\section{Chemicals and reagents}

All major chemicals/antibodies/culture media were of analytical/extra-pure research grade and purchased from Sigma Aldrich (USA)/Gibco BRL (Grand Island, NY, USA)/Tarsons (USA)/Cell Signalling Tech (USA) and BD Bioscience (USA).

\section{Isolation of Flavonol from ethanolic leaf extract of Thuja occidentalis}

The ethanolic (65\%) leaf extract of Thuja occidentalis, procured from Boiron laloratories, Lyon, France, was dried under vacuum (yield $17.2 \% \mathrm{w} / \mathrm{w}$ ). The dry extract was then mixed with petroleum ether $(50 \mathrm{ml}$ $\mathrm{v} / \mathrm{v}$ ) and the soluble portion was then taken out and again dried on a hot plate (yield 1-2\% w/w). After this evaporation, a brownish mass was found ${ }^{[18]}$. It was then loaded on to silicic acid column (60-120 mesh) using n-hexane and ethyl acetate as solvent system. Thereafter, 6 fractions (F1-F6) were collected at the polarity $8: 2(\mathrm{v} / \mathrm{v})$ of $\mathrm{n}$-hexane: ethyl acetate mixture. The concentration of each fraction in the solvent (n-hexane and ethyl acetate mixture) was measured. The maximum concentration $(100 \mathrm{mg} / \mathrm{ml})$ was found in the fraction 4 (F4).

\section{Flavonol confirmatory test}

After addition of $10 \% \mathrm{NaOH}$ to the 6 isolated fractions (F1-F6), only fraction 4 (F4) gave the yellow colouration, indicative of being flavonol-rich fractions ${ }^{[19]}$. Beside this, fraction 5 (F5) gave partial yellow coloration after addition of $10 \% \mathrm{NaOH}$. Thereafter, mass spectroscopy was done to identify the components of isolated fraction, which showed only the fraction 4 (F4) to be highly-flavonol rich. In this study, the desired amount of isolated fraction was mixed with solvent media and was sonicated with a probe sonicator for use in subsequent experiments. 


\section{Cell lines}

Human non-small cell lung carcinoma cell line, A549 and normal lung cell line, L-132 were collected from National Centre for Cell Science, Pune, India. The cells were cultured in DMEM with $10 \%$ heat inactivated $\mathrm{FBS}$ and $1 \%$ antibiotic (PSN) and maintained at $37^{\circ} \mathrm{C}$ with $5 \% \mathrm{CO}_{2}$ in a humidified incubator.

\section{Treatment of isolated flavonol fraction}

For MTT assay, A549 and L-132 cells were exposed to 6 isolated flavonol fractions named as F1-F6 at $37^{\circ} \mathrm{C}$ in DMEM supplemented with serum. As positive control equal volume of medium was added to the untreated cells. $I_{50}$ values were determined after 48 hours of incubation.

\section{Cell viability assay}

Briefly, A549 and L-132 cells were seeded in 96 well plates at a density of $1 \times 10^{2}$ cells per well and were allowed to settle for $24 \mathrm{~h}$ before treatment. Then the cells were treated with isolated fractions (F1-F6) (1$100 \mu \mathrm{g} / \mathrm{ml}$ ) for 48 hours with $5 \% \mathrm{CO}_{2}$ at $37^{\circ} \mathrm{C}$. Cell viability was measured by MTT assay. The control values corresponding with the untreated cells were taken as $100 \%$ and the viability data of treated ones were expressed as percentage of control.

\section{Animals}

A large group of healthy inbred strain of Swiss albino mice (Mus musculus) (6-8 weeks ; 20-25 g) were housed for at least 14 days in an environmentally controlled room (temp $24 \pm 20^{\circ} \mathrm{C}$, humidity $55 \pm 5 \%, 12$ hrs light/dark cycle) with access to food and water ad libitum. The experiments were conducted under supervision of the Animal Welfare Committee of the Department of Zoology and as per the approved guidelines of the Institutional Ethical Committee, University of Kalyani (892/OC/05/CPCSEA).

\section{Animal study design}

Swiss albino mice (Mus musculus) were randomized and those weighing between 20-25 gm were selected for the experiment. 12 mice were selected for each group. Flavonol fraction, F4 was given through gavages at a dose of $100 \mathrm{mg} / \mathrm{kg}$ bw daily to the "treatment groups" at different time points. Earlier, BaP was given at $50 \mathrm{mg} / \mathrm{kg}$ bw of dose for first 30 days (twice a week) to induce cancer after 120 days $^{[20]}$. The following experimental groups were selected for the study.
Group 1: Normal control- animals received no treatment and only standard food and water.

Group 2: Only flavonol (F4) treated group- Flavonol (F4) was fed orally for 120 days once daily, and thereafter chronic toxicity test was done.

Group 3: BaP fed group- animals received BaP dissolved in olive oil.

Group 4: Only olive oil fed group- received only olive oil.

Group 5: Animals received BaP for first 30 days and co-treated with flavonol (F4) orally from first day for 120 days.

Group 6: Animals received BaP for first 30 days and co-treated with flavonol (F4) after first 30 days and after that for 90 days.

Group 7: Animals received BaP for first 30 days and co treated with flavonol (F4) after first 60 days and after that for 60 days.

Group 8: Animals received BaP for first 30 days and co-treated with flavonol (F4) after first 90 days and after that for 30 days.

All the groups except group 1, 2 and 4 were fed orally $\mathrm{BaP}$ to develop lung tumors. The animals were humanely sacrificed under light ether anaesthesia and the target organs (lung and liver) were collected.

\section{Acute toxicity assay}

For acute toxicity, mice were reared under suitable condition. They were given the $\mathrm{F} 4$ at $25 \mathrm{mg} / \mathrm{kg}$ bw, $50 \mathrm{mg} / \mathrm{kg}$ bw, $100 \mathrm{mg} / \mathrm{kg}$ bw and $200 \mathrm{mg} / \mathrm{kg}$ bw. Behaviour was observed after $24 \mathrm{~h}$ of drug exposure.

\section{Chronic toxicity assay}

We fed F4 (100mg/kg bw) alone for 120 days and thereafter, peripheral blood mononuclear cells (PBMC) were isolated by Ficol-density gradient centrifugation $^{[21]}$ and liver tissue homogenates were made. For chronic toxicity assay cytotoxic analysis of PBMC was done by MTT assay ${ }^{[2]}$. Aspartate transaminase (AST) and Alanine transaminase (ALT) activities of liver tissue homogenates were determined $^{[23]}$.

\section{Tumor bioassay}

At 120 days mice in each group were sacrificed. For 
flow cytometric analysis, the cells were perfused and subsequent experiments were done. For microscopic and histological analysis, lung tissues were placed in $10 \%$ phosphate-buffered formalin.

\section{Scanning electron microscopic study}

Lung samples of normal, cancerous and F4-treated mice were immediately washed with PBS after dissection and were fixed with $2.5 \%$ glutaraldehyde $(\mathrm{pH}$ 7.2-7.4) for $24 \mathrm{~h}$. After fixation, tissues were dehydrated with graded series of acetone (50\%-100\%); keeping $20 \mathrm{~min}$ in each grade. The tissues were dried by critical point drying (CPD), cut into small and after gold coating, were observed and analysed by S530-Hitachi SEM instrument (Department of USIC, University of Burdwan).

\section{Histological analysis}

Fixed tissues were cut into $5 \mu \mathrm{m}$ single sections and was deparaffinised with xylene and stained thereafter with haematoxylin and eosin, following the standard protocol[24]. The images were captured under a light microscope (Leica, Germany).

\section{Confocal microscopy}

Tissue sections were deparaffinised with xylene and thereafter incubated with blocking solution (BSA with $0.5 \%$ Tween-20) for $1 \mathrm{~h}$. Then the sections were incubated overnight with anti-Akt (1:50) and anti-caspase 3 (1:50) primary antibodies. Thereafter, sections were washed with PBST (PBS with 0.5\% TWEEN-20) and PBS with 3 changes each. Sections were then incubated with FITC-tagged secondary antibody (1:100) for 30 minutes. After that, DAPI $(10 \mu \mathrm{M})$ stain was added and tissue sections were viewed under Carl Zeiss LSM 510 META Laser Scanning Microscope.

\section{Apoptosis related assay}

The lung tissues were minced within RPMI-1640 media with $5 \%$ FBS and the lung cells were flushed gently using a hypodermic syringe. The media-containing cells were spun down at $1000 \mathrm{~g}$ and the supernatant-containing lung cells were used for further study ${ }^{[25]}$. $2 \times 10^{7}$ cells were dual-stained with AnnexinV-FITC (100ng/ml) and PI $(50 \mu \mathrm{g} / \mathrm{ml})$ to check phosphatidylserine externalization, if any ${ }^{[26]}$. For caspase 3 expression analysis, caspase 3 positive cell population was then quantified by FACS Calibur (BD Bioscience, USA) after labelling the cells with anti-caspase 3 antibody (1:50) for $2 \mathrm{hr}$ and thereafter with FITCtagged secondary antibody (1:100) for 30 minutes.

\section{Intracellular ROS accumulation study}

Intracellular ROS accumulation assay was done after staining the perfused cells $\left(2 \times 10^{7}\right.$ cells/sample $)$ with DCFDA $(10 \mu \mathrm{M})$ for 30 minutes in dark ${ }^{[27]}$. ROS accumulation was then quantified by FACS Calibur (BD Bioscience USA).

\section{Reverse transcriptase polymerase chain reaction (RT-PCR) analysis}

Lung tissue samples were washed with ice-cold PBS. Then, total RNA was extracted from lung sample of normal, cancerous and flavonol fed mice and equal amount of RNA was subjected to RT reaction ${ }^{[28]}$. Thereafter, mRNA expression levels of PI3K, Akt, p53, Bax and $\mathrm{Bcl} 2$ was analysed by measuring the band intensities on the agarose gel using the image $\mathrm{J}$ software ${ }^{[29]}$. GAPDH was taken as housekeeping gene control. The oligonucleotide (primer) sequences are mentioned in table 1.

\section{Preparation of lung tissue homogenates and pro- tein isolation}

$50 \mathrm{mg}$ lung tissue samples were taken and washed twice with ice cold PBS. Then for total protein isolation, tissue sample was lysed in $2 \mathrm{ml}$ of ice-cold lysis buffer and for cytoplasmic protein isolation, tissue sample was lysed in cytoplasmic protein extraction buffer ${ }^{[30]}$.

\section{FRAP assay}

We determined antioxidant capacity of isolated flavonol on alveolar tissues of normal, cancerous and flavonol fed animals by FRAP (ferric reducing antioxidant potential) assay ${ }^{[31]}$.

\section{Estimation of Anti-oxidants level}

The activities of major anti-oxidants like reduced glutathione $(\mathrm{GSH})^{[32]}$ and superoxide dismutase (SOD) [33] from lung tissue homogenates were spectrophotometrically analysed.

\section{Indirect ELISA}

Equal amount $(20 \mu \mathrm{g})$ was taken for indirect ELISA. Akt, p-Akt, PI3K and GAPDH protein expressions were then analyzed by indirect ELISA according to the manufacturer's protocol (Santa Cruz Biotechnology, Inc., USA).

\section{Western blot analysis}


For western blot analyses equal amount $(70 \mu \mathrm{g})$ of protein was loaded and samples were denatured by SDS-PAGE. The separated proteins were transferred separately onto PVDF membranes and were probed with p53 (1:500), Akt (1:500), p-Akt (1:1000), PI3K (1:500), PARP (1:1000), Bax (1:500), Bcl2 (1:500), caspase 3 (1:1000) and GAPDH (1:1000) followed by $1 \mathrm{~h}$ incubation with ALKP conjugated secondary antibody (1:500) and were developed by BCIP-NBT ${ }^{[34]}$. Thereafter, band intensities were quantified by densitometry using image $\mathrm{J}$ software ${ }^{[29]}$.

\section{Statistical analysis}

All the data reported were the arithmetic means of data of independent experiments performed in triplicate. Results were expressed as mean \pm SD (standard deviation), unless otherwise stated. Statistical analysis was made by the one-way analysis of variance (ANOVA) with LSD post-hoc test using SPSS 16 software (SPSS Inc, Chicago, IL, USA). Statistical significance was considered as ${ }^{\$} P<0.05,{ }^{\$} P<0.01$, ${ }^{\$ \$} \mathrm{P}<0.001$ between $\mathrm{BaP}$ intoxicated group vs. normal control group, ${ }^{*} \mathrm{P}<0.05,{ }^{* *} \mathrm{P}<0.01,{ }^{* * *} \mathrm{P}<0.001$ between flavonol treated groups vs. BaP intoxicated group and ${ }^{\#} \mathrm{P}<0.05,{ }^{\#} \mathrm{P}<0.01,{ }^{\# \#} \mathrm{P}<0.001$ between flavonol treated groups vs. normal control group.

\section{Results}

\section{Isolation and identification of flavonol fraction}

6 fractions arbitrarily designated as F1, F2, F3, F4, $\mathrm{F} 5$ and $\mathrm{F} 6$ were successfully isolated from the Thuja occidentalis leaf extract. Among them only F4 gave the yellow colouration after addition of $10 \% \mathrm{NaOH}$ indicative of being the flavonol-rich fraction. However, mass spectral analysis revealed the presence of flavonols like quercetin, kaempherol in a higher proportion only in the fraction 4 (F4).

\section{Isolated flavonol fraction (F4) reduced A549 cell viability}

MTT assay revealed F4 and F5 to have significantly more cytotoxicity in A549 cells, than the other fractions, F1, F2, F3 and F6. F4 showed maximum cytotoxicity $\left(\mathrm{IC}_{50}\right.$ value being $\left.7.5 \mu \mathrm{g} / \mathrm{ml}\right)$ in lung cancer cell line (A549), but the normal lung cells (L132) after $48 \mathrm{~h}$ of incubation remained least affected $\left(\mathrm{IC}_{50}\right.$ value being $>1000 \mu \mathrm{g} / \mathrm{ml}$ ) (Table 2). On the other hand, F5 showed partial cytotoxicity both in the A549 $\left(\mathrm{IC}_{50}\right.$ value being $10 \mu \mathrm{g} / \mathrm{ml})$ and $\mathrm{L}-132\left(\mathrm{IC}_{50}\right.$ value being 27.2 $\mu \mathrm{g} / \mathrm{ml}$ ) cells.

\section{Flavonol toxicity assessment}

In acute toxicity, no behavioural changes or behavioural abnormalities were observed in the mice at a dose of $100 \mathrm{mg} / \mathrm{kg}$ body weight F4 which was used in the experiment while partial behavioural changes and rapid movement were observed at the doses of $200 \mathrm{mg} / \mathrm{kg}$ body weight.

In chronic toxicity test, no significant alterations were found in PBMC viability and ALT and AST activities between normal and only flavonol fraction 4 (100 mg/ $\mathrm{kg} \mathrm{bw}$ ) treated groups (Figure 1A). In case of olive oil (solvent of BaP) fed mice (group 4) no significant recovery was observed. Therefore, we excluded group 2 (only flavonol treated group) and group 4 (olive oil fed group) from further in-depth studies.

\section{Flavonol (F4) treated animals showed lower lung tumor load compared to BaP-intoxicated animals}

Reduction in numbers of lung tumor nodules was observed in BaP plus F4 treated mice (group 5, group 6 , group 7 and group 8 ) as compared to only BaP intoxicated ones (group 3). Flavonol-4 fed specially at the later phase of carcinogenesis (group 7 and 8) was found to be more effective in reducing lung tumor nodules than in the other two groups (group 5 and 6 ) fed flavonol from initial stages of carcinogen treatment.

\section{Flavonol (F4) treatment recovered lung tissue ar- chitecture}

In BaP induced mice, alveolar cells were found to be denser and alveolar spaces were reduced as compared to the normal ones. In case of simultaneous flavonol treatment for all tested time points, tissue structure and alveolar spaces regained proper shape and architecture (Figure 1B) of lung.

SEM study revealed the architectural distortion of alveolar vasculature due to $\mathrm{BaP}$ induction as compared to that of the normal ones. Reduction of alveolar spaces and uneven surface topology were also prominent in the BaP induced cancerous lung. Simultaneous flavonol administration recovered the architectural pattern including that of the surface topology in the lung tissue section. Flavonol administration for 60 and 30 days (Group 7 and 8), respectively, was found to be more effective in recovering alveolar tissue architecture than in the other two flavonol fed groups (Figure 1C). 
Fig.1.

A.

\begin{tabular}{ccc}
\hline $\begin{array}{c}\text { \% Of Normal } \\
\text { Control }\end{array}$ & Normal & $\begin{array}{c}\text { Flavonol } \\
\text { treated (100 } \\
\text { mg/kg b.w.) }\end{array}$ \\
\hline PBMC (live cells) & $100 \pm 1.35$ & $98.03 \pm 4.41$ \\
\hline ALT activity & $100 \pm 0.71$ & $94.96 \pm 1.43$ \\
\hline AST activity & $100 \pm 0.34$ & $100 \pm 1.59$
\end{tabular}

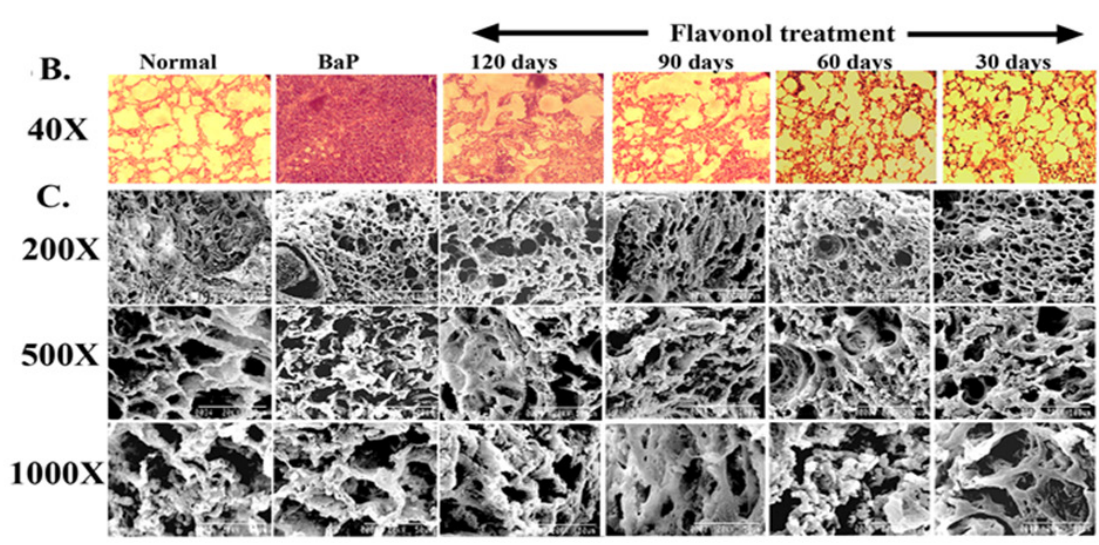

Fig. 1. Isolated flavonol and its effect on lung tissue architecture. (A) Chronic toxicity assay of flavonol. PBMC viability and ALT, AST activity measurement of liver tissue were done. All the data were expressed as percentage of control and presented as mean $\pm S D$. (B) Histological analysis after Eosin-Haematoxylin staining. Lung tissue sections were deparaffinised and stained with eosin and haematoxylin to observe alveolar tissue architecture under the light microscope. (C) Scanning electron microscopical (SEM) study of lung tissue to observe tissue distortion, alveolar structure in details.
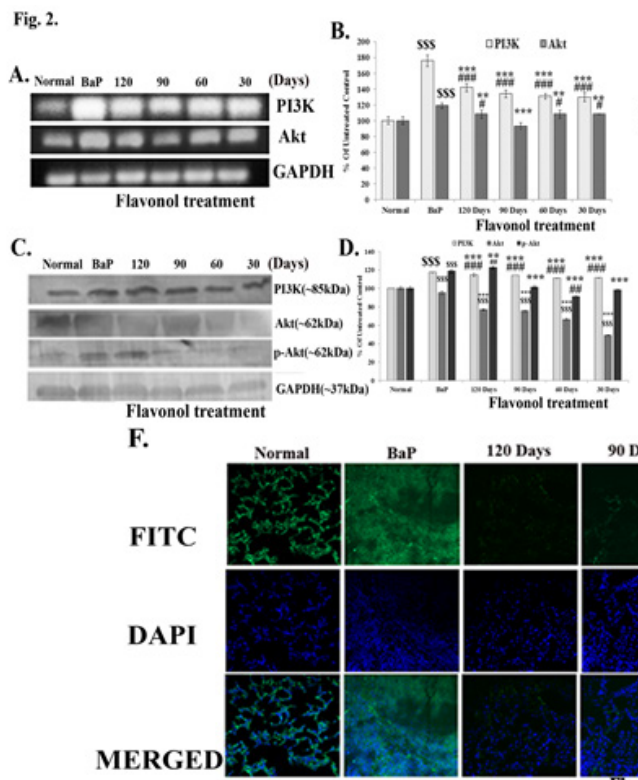

E.

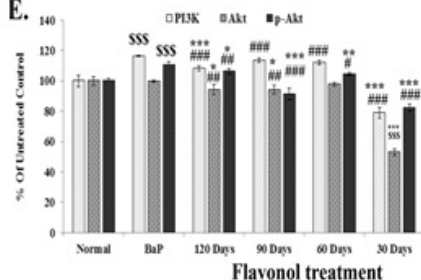

Fig. 2. Effect of flavonol on the constitutive and activated expression of Akt. (A) RT-PCR analysis of proliferation related gene analysis. RT-PCR of PI3K, Akt, and GAPDH was done. (B) Relative band intensities of PI3K, Akt were calculated. GAPDH was taken as housekeeping gene control. Data were expressed as percentage of control and presented as mean $\pm S D$. $\$ \$ \$ P<0.001$, \#P<0.05, $\# \# \# P<0.001,{ }^{* *} \mathrm{P}<0.01,{ }^{* * *} \mathrm{P}<0.001$ were considered as statistically significant. (C) Western blots of PI3K, Akt, p-Akt, GAPDH was done. (D) Relative band intensities of PI3K, Akt, p-Akt was calculated. GAPDH was taken as housekeeping gene control. Data were expressed as percentage of control and presented as mean \pm SD . $\$ \$ \$ P<0.001, \# \# P<0.01, \# \# P<0.001,{ }^{* *} P<0.01,{ }^{* * *} P<0.001$ were considered as statistically significant. $(E)$ Indirect ELISA of PI3K, Akt, p-Akt was done. Data were expressed as percentage of control and presented as mean \pm SD. $\$ \$ \$ P<0.001, \# \# P<0.01, \# \# \#<0.001,{ }^{*} \mathrm{P}<0.05,{ }^{* *} \mathrm{P}<0.01$,

${ }^{* * *} P<0.001$ were considered as statistically significant. $(F)$

Expression of Akt after flavonol treatment by confocal microscopy was analysed. Tissue sections were incubated with Akt antibody. Thereafter the tissue sections were incubated with FITC-tagged secondary antibody and counterstained with DAPI to explain modulation of Akt expression after flavonol treatment as compared with the $\mathrm{BaP}$ intoxicated ones.

Fig.3.

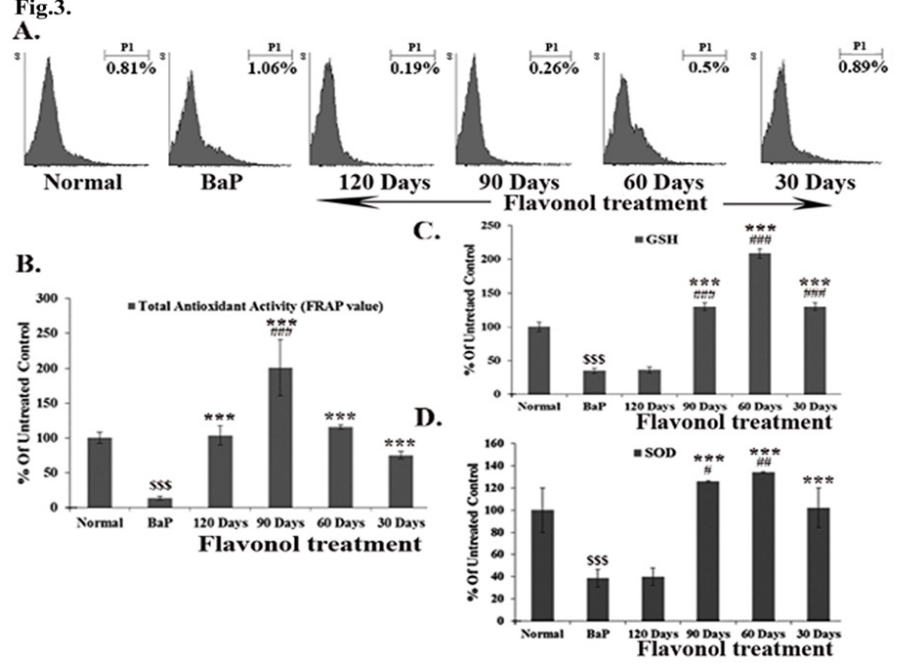

Fig. 3. Effect of flavonol on ROS generation and antioxidant enzyme contents. (A) Perfused lung cells of treated and untreated mice were stained with DCFDA $(10 \mu \mathrm{M})$ and intercellular ROS generation was analysed after FACS analysis. (B) Total antioxidants value was estimated by FRAP assay from lung tissue homogenates of treated and untreated mice. Data were expressed as percentage of control and presented as mean $\pm \mathrm{SD}$. $\$ \$ \$ P<0.001$, \#\#\#P<0.001, ${ }^{* * *} \mathrm{P}<0.001$ were considered as statistically significant. (C) GSH content was estimated and the data were presented as mean \pm SD taking percentage of control. $\$ \$ \$ P<0.001, \# \# \# P<0.001,{ }^{* * *} P<0.001$ were considered as statistically significant. (D) SOD activity of untreated and treated mice lung tissue homogenates was estimated. . Data were expressed as percentage of control and presented as mean $\pm \mathrm{SD}$. $\$ \$ \$ P<0.001$, $\# \mathrm{P}<0.05, \# \# \mathrm{P}<0.01,{ }^{* * *} \mathrm{P}<0.001$ were considered as statistically significant. 
Flavonol (F4) blocked proliferation through down-regulation of both constitutive and PI3K-activated expression of Akt

Assays like- RT-PCR, indirect ELISA and western blot analyses revealed significant down-regulation of constitutive Akt expression upon flavonol treatment (Figure 2A-2E).

In the flavonol treated mice, PI3K level was down-regulated both at gene and protein levels as analysed from RT-PCR, indirect ELISA and western blot results (Figure 2A-2E). p-Akt, a PI3K mediated activated form of Akt, was also down-regulated upon flavonol treatment as revealed from indirect ELISA and western blot analyses (Figure 2A-2D). Hence, these findings suggested that flavonol was also able to down-regulate $\mathrm{PI} 3 \mathrm{~K}$ mediated activated expression of Akt.

In the $\mathrm{BaP}$ induced cancerous tissue, confocal imaging indicated that the expression level of Akt got up-regulated as indicated by intense green fluorescence. However, in flavonol treated lung tissues, lesser intense green fluorescence level, merged with intense blue fluorescence of DAPI were found (Figure $2 \mathrm{~F}$ ). This would indicate down-regulation of Akt expression upon F4 treatment, compared to that of $\mathrm{BaP}$ intoxicated drug untreated ones.

Flavonol fraction scavenged reactive oxygen species (ROS) and up-regulated level of antioxidant enzymes

An up-regulation of ROS (1.06\%) in BaP induced mice perfused lung cells was observed as compared to that in the normal mice lung cells $(0.81 \%)$. This was in conformity with earlier report ${ }^{[33]}$ which demonstrated that $\mathrm{BaP}$ mediated its toxicity by elevating ROS level and ROS-mediated DNA damage. However, upon flavonol treatment BaP induced ROS level was down-regulated in a significant proportion especially in the mice fed with the isolated flavonol-4 for 120 and 90 days (groups 5 and 6, respectively) (Figure 3A).

Along with this, levels of the total antioxidants including that of major antioxidants like- GSH and SOD was down-regulated after $\mathrm{BaP}$ exposure, which might be due to the elevated ROS level. FRAP and antioxidant enzymatic assay data thus revealed that total antioxidant levels (Figure 3B) including that of GSH (Figure 3C) and SOD (Figure 3D) were increased after flavonol treatment, as compared to that of only
BaP-intoxicated ones.

\section{Flavonol (F4) induced apoptosis of BaP intoxicat- ed mice lung cells}

Flow cytometric data revealed that significant number of lung cells showed annexin $V$ positivity, indicating thereby ability of flavonol in inducing apoptosis causing destruction/regression of $\mathrm{BaP}$ exposed lung tumor (Figure 4A).

FACS data revealed an up-regulation of activated caspase 3 positive cell population, especially in the flavonol treatment groups 7 and $8(5.3 \%$ and $4.3 \%$, respectively) as compared to that of normal ones $(0.7 \%)$ (Figure 4B). Confocal imaging also revealed an up-regulated cytoplasmic expression of caspase 3 , as indicated by brighter green fluorescence (Figure $4 \mathrm{C}$ ). From western blot data, we observed a significant up-regulation of cleaved caspase 3 at 17 $\mathrm{kDa}$ and PARP at $89 \mathrm{kDa}$ fragments (Figure 4D-4E). These would indicate flavonol induced apoptotic cell death in lung tumor of $\mathrm{BaP}$ intoxicated mice. Elevated level of caspase 3 induces DNA fragmentation and thereby helps in the process of apoptotic cell death $^{[34]}$.

\section{Flavonol (F4) modulated gene and protein ex- pressions related to apoptosis}

From RT-PCR and western blot data we got an increased expression of p53 and Bax along with decreased expression of $\mathrm{Bcl} 2$ in the lung of flavonol treated mice than that in the drug untreated $\mathrm{BaP}$ intoxicated ones (Figure 5A-5D). Hence, after flavonol treatment, both at gene and protein levels, Bcl2/Bax ratio had been decreased (Figure 5E) that would rather provoke the cells to progress towards apoptosis.

\section{Discussion}

Our in vitro studies revealed that among all six flavone-rich fractions, F4, had significant cytotoxic effects against $A 549$ cells, but no or little effect on normal L-132 lung cells. Besides, we have also found F5-induced partial cytotoxicity both in lung cancer cell lines, A549 and the normal lung cells, L-132. This suggests that though this fraction (F5) bears partial amount of flavonols but may also bear some toxic impurities that might be detrimental both for the cancer cells along with their normal counterparts which is undesirable. Therefore, the fraction 5 (F5) was not continued for other assays. F4 was taken as the lead 


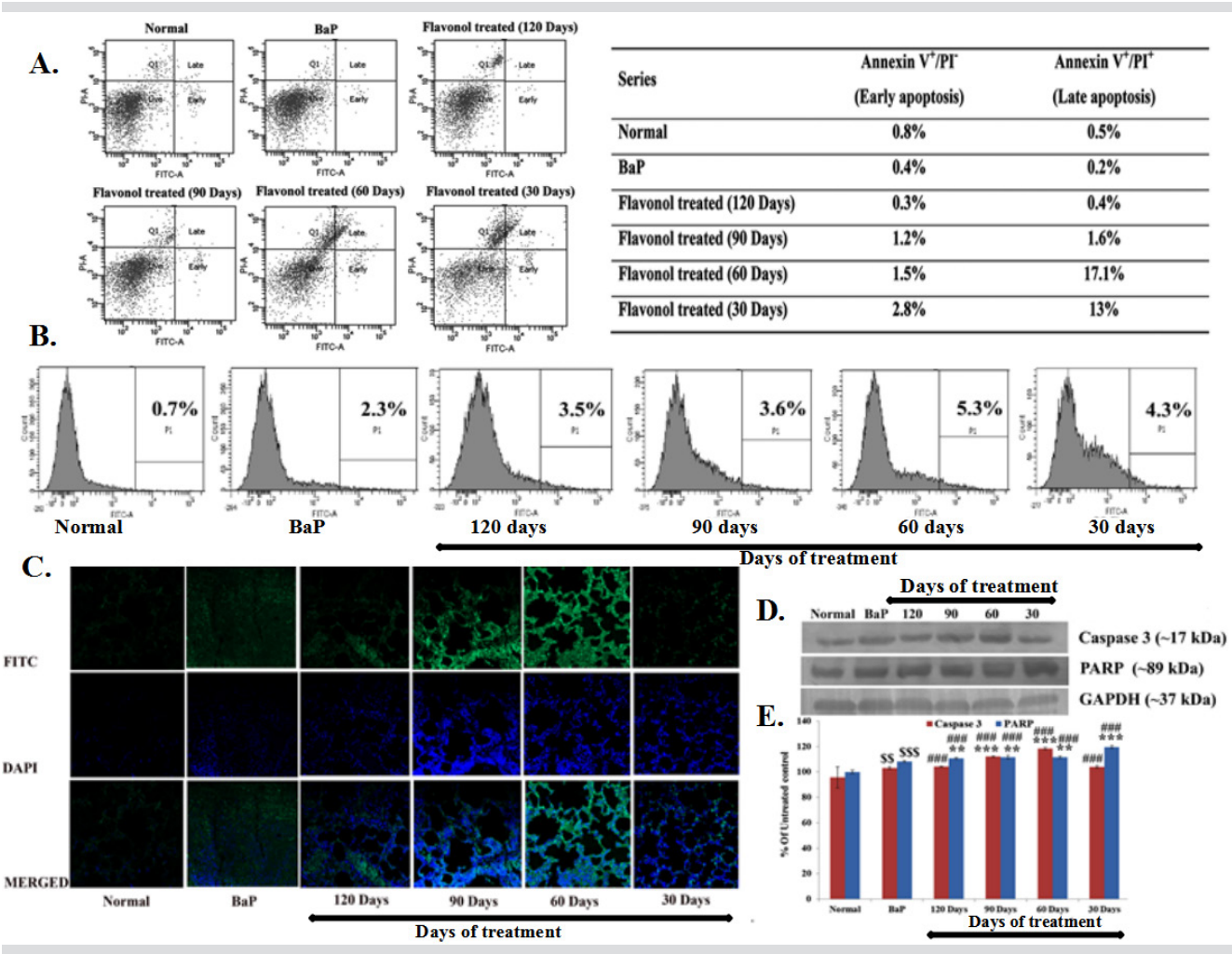

Fig. 4. Influence of flavonol in conducting apoptosis. (A) Perfused lung cells of different treated groups and untreated ones were stained with annexinV-FITC and PI and FACS analysis was done. The number of annexinV positive cells was determined and the percentage was represented in lower right quadrant (Annexin V+/PI-) and upper right quadrant (Annexin V+/PI-). (B) Perfused lung cells of normal mice and mice of different treated groups and untreated ones were incubated with caspase 3 antibody and furthermore FITC-tagged secondary antibody. Thereafter percentage of caspase 3 positive cell population was analysed by FACS analysis. (C) Mice lung tissue sections of different groups were incubated with caspase 3 antibody and FITC-tagged secondary antibody. Thereafter, the tissue sections were counterstained with DAPI and caspase 3 expression was

visualized by confocal microscopic images. (D) Western blot assay of caspase3, PARP, GAPDH was done. (E) Band intensities of caspase3, PARP were calculated. GAPDH was used for loading correction. Data were expressed as percentage of control and presented as mean \pm SD. $\$ \$ P<0.01, \$ \$ \$ P<0.001, \# \# \mathrm{P}<0.001,{ }^{* *} \mathrm{P}<0.01,{ }^{* * *} \mathrm{P}<0.001$ were considered as statistically significant.

Fig. 5.

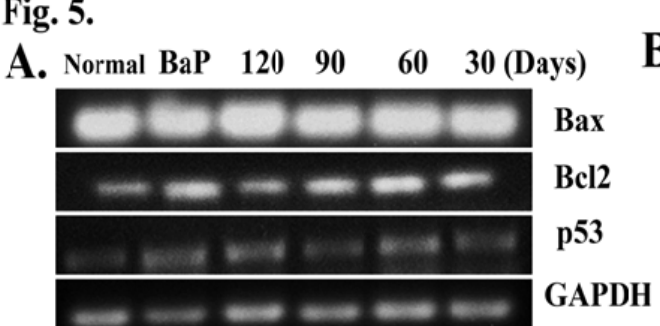

Flavonol treatment

E.

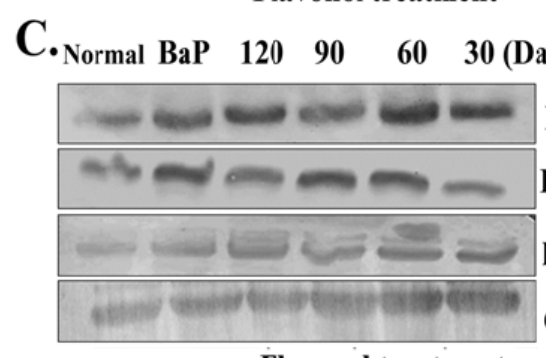

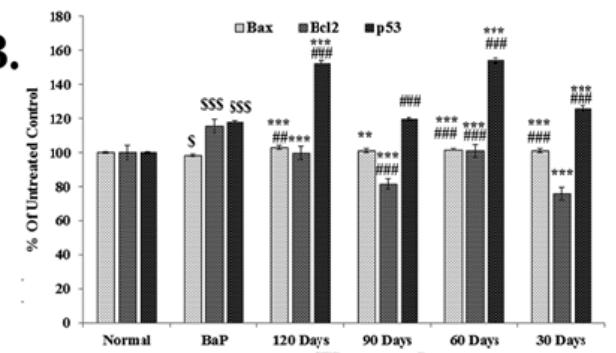

Flavonol treatment

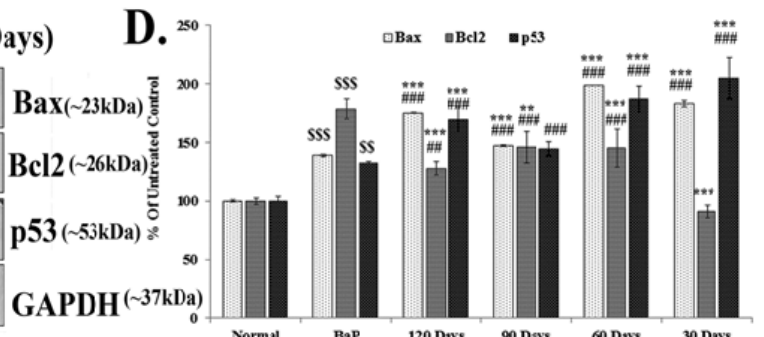

Flavonol treatment

\begin{tabular}{|c|c|c|c|c|c|c|}
\hline $\mathrm{Bcl} / \mathrm{Bax}$ & Normal & $\mathrm{BaP}$ & $\begin{array}{l}\text { 120 Days } \\
\text { (Flavonol } \\
\text { treatment) }\end{array}$ & $\begin{array}{l}90 \text { Days } \\
\text { (Flavonol } \\
\text { treatment) }\end{array}$ & $\begin{array}{l}60 \text { Days } \\
\text { (Flavonol } \\
\text { treatment) }\end{array}$ & $\begin{array}{l}30 \text { Days } \\
\text { (Flavonol } \\
\text { treatment) }\end{array}$ \\
\hline RT-PCR & $0.99 \pm 0.996$ & $1.17 \pm 0.046^{\text {sss }}$ & $0.96 \pm 0.039^{* * *}$ & $0.80 \pm 0.039^{\ldots \# \#}$ & $0.99 \pm 0.041^{* * *}$ & 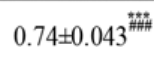 \\
\hline Western Blot & $0.99 \pm 0.038$ & $1.28 \pm 0.047^{\text {sss }}$ & $0.72 \pm 0.030^{\# \#}$ & $0.99 \pm 0.098^{* * * *}$ & $0.72 \pm 0.082^{\ldots \ldots \#}$ & $0.49 \pm 0.036$ \\
\hline
\end{tabular}

Fig. 5. Effect of flavonol on apoptosis related gene expression. (A) RT-PCR of Bax, $\mathrm{Bcl} 2$, p53, GAPDH was done. (B) Relative band intensities of $\mathrm{Bax}, \mathrm{Bcl} 2$ and $\mathrm{p} 53$ were calculated. GAPDH was used for loading correction. Data were expressed as percentage of control and presented as mean $\pm S D . \$ P<0.05$, $\$ \$ \$ P<0.001, \# P<0.05$, \#\#P<0.01, \#\#\#P<0.001, ${ }^{* *} \mathrm{P}<0.01$, ${ }^{* * *} \mathrm{P}<0.001$ were considered as statistically significant. (C) Western blot of $\mathrm{Bax}, \mathrm{Bcl} 2, \mathrm{p} 53$ and GAPDH was done. (D) Relative band intensities of $\mathrm{Bax}, \mathrm{Bcl} 2$ and p53 were calculated. GAPDH was used for loading correction. Data were expressed as percentage of control and presented as mean $\pm S D$. $\$ \$ P<0.01, \$ \$ \$ P<0.001$, \#\#P<0.01, \#\#\#P<0.001, ${ }^{* *} \mathrm{P}<0.01,{ }^{* * *} \mathrm{P}<0.001$ were considered as statistically significant. $(\mathrm{E}) \mathrm{Bcl} 2$-Bax ratio both at gene and protein levels was calculated. Results were presented as mean $\pm \mathrm{SD}$. Data were expressed as percentage of control and presented as mean $\pm \mathrm{SD}$. $\$ \$ \$ P<0.001, \# \# \#<0.001,{ }^{* * *} \mathrm{P}<0.001$ were considered as statistically significant. 
compound bearing the flavonols in a higher proportion than the other isolated fractions.

For in vivo studies the protective dose was optimized at $(100 \mathrm{mg} / \mathrm{kg} \mathrm{bw})$ for F4. When this dose was administered to normal mice, no acute or chronic toxicity was found, but a significant reduction of lung tumor burden was noted in BaP intoxicated mice. Histological studies under normal microscope and SEM indicated that F4 treatment lowered the tumor burden, alveolar distortion and improved tissue architecture.

Further, expression levels of several anti-proliferative and apoptotic related genes were favourably modulated by $\mathrm{F} 4$ administration in BaP treated mice. As for example, favourable modification in expression of Akt, which is known to an important regulator of proliferation and differentiation ${ }^{[37,38]}$ involved in $\mathrm{BaP}$ induced lung carcinogenesis, was noted. F4 also favourably modulated PI3-kinase, which is an upstream effector of Akt activation ${ }^{[39]}$. This was further supported by results of RT-PCR, indirect ELISA and western blot.

FACS analysis showed significant number of perfused cells from flavonol treated mice lung tissue to respond positively with annexinV-FITC and caspase 3. Western blot and confocal microscopic data also supported the cytosolic up-regulation of cleaved caspase 3 (17 kDa fragment) along with overexpression of cleaved PARP fragment $(89 \mathrm{kDa})$ in the flavonol treated lung tissue as compared to the normal and BaP intoxicated ones. In this study, RT-PCR and western blot data revealed the alteration of $\mathrm{Bcl} 2 /$ Bax ratio upon administration of the isolated fraction. Up-regulation of Bax and down-regulation of $\mathrm{Bcl} 2$ therefore suggested that F4 induced apoptosis in the $\mathrm{BaP}$ intoxicated lung tissue of mice.

p53, a tumor suppressor gene, and Akt, are two major and opposing molecules in apoptotic signaling pathway, which display a cross talk between them, Akt, affecting down-regulation of p53 and p53-dependent signaling activities. Thus the observation of p53 up-regulation along with Akt down-regulation upon flavonol (F4) treatment in this study was significant in the context of induction of apoptosis.

As BaP exerts its carcinogenic effect by up-regulation of ROS level and thereby deregulate the redox state of cells; this in turn initiates oxidative tissue damage. The efficacy of this isolated fraction in scavenging BaP-induced ROS activity was analysed. Results of fluorometric study suggested that elevated level of
ROS due to carcinogen induction was down-regulated by the administration of flavonol (F4) especially in the mice of group 5 and 6 than in the other two groups (group 7 and 8). Analysis of data from FRAP and enzymatic assays revealed increased level of activities of both the total antioxidants and major antioxidants like- GSH, SOD after treatment with the isolated fraction. Sum total of these activities could be attributed to the lowering of BaP induced toxicity level in mice.

Flavonol (F4) could modulate ROS and antioxidant enzymatic activity more significantly when it was administered to $\mathrm{BaP}$ intoxicated mice right from the beginning (group 5 and 6 mice). On the other hand, this isolated fraction also reduced BaP induced carcinogenicity, presumably by the combined effects of down-regulating both the constitutive and PI3K induced Akt activity, blocking the uncontrolled lung cell proliferation, and thereafter by inducing apoptotic cell death. However, ability to induce apoptosis by the isolated flavonols was found to be relatively more pronounced especially in mice of group 7 and 8 , which presumably represented late phase of $\mathrm{BaP}$ induced tumorigenesis. This would indicate that if this isolated flavonol fraction (F4) was unable to block the entry of BaP metabolites into the lung cells, it still succeeded in effectively blocking the toxic activity of BaP rather mechanistically.

To determine the proper human dose equivalence, extrapolation was necessary from the dose used in mice here. For this, the dose translated in human system following body surface area normalization can be calculated by the method of Reagan-Shaw et al. ${ }^{[40]}$. Based on this the equivalent dose of flavonol used in mice $(100 \mathrm{mg} / \mathrm{kg} \mathrm{bw})$, the human dose can be calculated by the following formula:

Human equivalent dose $(\mathrm{mg} / \mathrm{kg})=$ Animal dose $(\mathrm{mg} /$ $\mathrm{kg}) \times($ Animal $\mathrm{Km}$ factor/Human $\mathrm{Km}$ factor $), \mathrm{Km}$ factor for mouse $=3 ; \mathrm{Km}$ factor for an adult human $=37$. If the body weight of a normal person is considered to be $70 \mathrm{~kg}$, then almost $0.56 \mathrm{~g}$ of this isolated flavonol fraction (F4) will be needed for a person per day to produce almost equal level of anti-lung carcinogenic effects as observed in mice. The dose seems to be sensible and attainable.

Earlier reports on several studies have suggested the flavonols as a major anticancer agent though the exact mechanism of it in lowering the lung cancer proliferation and tumorigenesis has not been elucidated in details so far ${ }^{[9,41,42,43]}$. Therefore the results of the present study have gained the significance over the 
Table 1. Primer sequences used for RT-PCR.

\begin{tabular}{cc}
\hline Primer name & Primer sequences \\
& Fwd 5'-TTAAACGCGAAGGCAACGA-3' \\
Rev 5'-CAGTCTCCTCCTGCTGCTGAT-3' & Fwd 5'-CCTGGACTACCTGCACTCTCGGAA-3' \\
& Rev 5'-TTGCTTTCAGGGCTGCTCAAGAAGG-3' \\
\hline Akt & Fwd 5'-AGTAACATGGAGCTGCAGAGG-3' \\
& Rev 5'-ATGGTTCTGATCAGTTCCGG-3' \\
Bax & Fwd 5'-GTGACTTCCGATCAGGAAGG-3' \\
& Rev 5'-CTTCCAGACATTCGGAGACC-3' \\
Bcl2 & Fwd 5'-GGAAATTGTATCCCGAGTATCTG-3' \\
& Rev 5'-GTCTTCCAGTGTGATGATGGTAA-3' \\
P53 & Fwd 5'-CCATGTTCGTCATGGGTGTGAACCA-3' \\
& Rev 5'-GCCAGTAGAGGCAGGGATGATGTTC-3' \\
\hline GAPDH & \\
&
\end{tabular}

Table 2- Isolated fraction and the calculated IC ${ }_{50}$ values on A549 and L-132 cells

\begin{tabular}{|c|c|c|}
\hline Fraction Name & & \\
\hline F1 & $\begin{array}{c}\text { A549 } \\
>50 \mu \mathrm{g} / \mathrm{ml}\end{array}$ & $\begin{array}{c}L-132 \\
>951 \mu \mathrm{g} / \mathrm{ml}\end{array}$ \\
\hline F2 & $>50 \mu \mathrm{g} / \mathrm{ml}$ & $>1000 \mu \mathrm{g} / \mathrm{ml}$ \\
\hline F3 & $>50 \mu \mathrm{g} / \mathrm{ml}$ & $>1000 \mu \mathrm{g} / \mathrm{ml}$ \\
\hline $\begin{array}{l}\text { F4 } \\
\text { F5 }\end{array}$ & $\begin{array}{r}7.5 \mu \mathrm{gg} / \mathrm{ml} \\
10 \mu \mathrm{g} / \mathrm{ml}\end{array}$ & $\begin{array}{c}>1000 \mu \mathrm{\mu g} / \mathrm{ml} \\
27.2 \mu \mathrm{mg} / \mathrm{ml}\end{array}$ \\
\hline F6 & $>50 \mu \mathrm{g} / \mathrm{ml}$ & $>1000 \mu \mathrm{g} / \mathrm{ml}$ \\
\hline
\end{tabular}

How to cite this article:

Avinaba Mukherjee, Sourav Sikdar and Anisur Rahman Khuda-Bukhsh (2016). Evaluation of ameliorative potential of isolated flavonol fractions from Thuja occidentalis in lung cancer cells and in Benzo(a)pyrene induced lung toxicity in mice.International Journal of Traditional and Complementary Medicine,1(1): 0001-0013. 
bther reports. Collectively, the present data indicated that flavonols of Thuja occidentalis extract were able to lower the toxicity of BaP by oxidative stress modulation and later it blocked $\mathrm{BaP}$ induced lung cancer proliferation by down-regulation of PI3K/Akt pathways. This isolated fraction also induces apoptotic activity in inhibiting $\mathrm{BaP}$ induced lung carcinogenesis with potential involvement of p53 up-regulation, Bcl2/ Bax dysregulation and caspase 3 activation, the qualities often sought for formulating effective anticancer drugs.

\section{Conclusion}

The current study validates that the flavonols of Thuja occidentalis possess ameliorative ability against BaP induced lung toxicity in mice. Therefore, the present study should be nominated to formulate target specific and chemopreventive anti-lung cancer agents in future.

\section{Acknowledgements}

Grateful acknowledgements are made to Dr. Srikanta Chakraborty, University of Burdwan, Dr. Sanjaya Mallick, Application Scientist and COE Manager, BD, CRNN, Dr. Dhrubyojyoti Chatterjee and Dr. Arunava Roy of University of Calcutta for their kind support providing various scientific and technical helps. Some chemicals used were from earlier project of Boiron Laboratories, Lyon, France.

\section{Conflict of interest}

None to declare

\section{References}

1. Rebecca L, Siegel MPH, Kimberly D, Miller MPH, Ahmedin-Jemal DVM. Cancer statistics. CA: A Cancer Journal for Clinicians 2016; 66:7-30.

2. Asokkumar S, Naveenkumar C, Raghunandhakumar S, Kamaraj S, Anandakumar P, Jagan S, Devaki T. Antiproliferative and antioxidant potential of beta-ionone against benzo(a)pyrene-induced lung carcinogenesis in Swiss albino mice. Mol. Cell. Biochem
$2012 ; 363: 335-345$

3. Sikdar S, Mukherjee A, Ghosh S, Khuda-Bukhsh AR. Condurango glycoside-rich components stimulate DNA damage-induced cell cycle arrest and ROS-mediated caspase-3 dependent apoptosis through inhibition of cell-proliferation in lung cancer, in vitro and in vivo. Environ. Toxicol. Pharmacol. 2014; 37:300-314.

4. Kazerouni N, Sinha R, Hsu CH, Greenberg A, Rothman N. Analysis of 200 food items for benzo[a]pyrene and estimation of its intake in an epidemiologic study. Food. Chem. Toxicol. 2001; 39:423-436.

5. Kim HS, Lee BM. Inhibition of benzo[a]pyrene-DNA adduct formation by Aloe barbadensis Miller. Carcinogenesis 1997; 18:771-776.

6. Barnes SL, Singletary KW, Frey R. Ethanol and acetaldehyde enhance benzo[a]pyrene-DNA adduct formation in human mammary epithelial cells. Carcinogenesis 2000; 21: 2123-2128.

7. Briede JJ, Godschalk RW, Emans MT, De-Kok TM, Van-Agen E, Van-Maanen J, Van-Schooten FJ, Kleinjans JC. In vitro and in vivo studies on oxygen free radical and DNA adduct formation in rat lung and liver during benzo[a]pyrene metabolism. Free. Radic. Res 2004; 38:995-1002.

8. Busch C, Burkard M, Leischner C, Lauer UM, Frank J, Venturelli S. Epigenetic activities of flavonoids in the prevention and treatment of cancer. Clin. Epigenetics $2015 ; 7: 64$.

9. Cui Y, Morgenstern H, Greenland S, Tashkin DP, Mao JT, Cai L, Cozen W, Mack TM, Lu QY, Zhang ZF. Dietary flavonoid intake and lung cancer-a population-based case-control study. Cancer 2008; 112:2241-2248.

10. Martinez-Perez C, Ward C, Cook G, Mullen P, McPhail D, Harrison DJ, Langdon SP. Novel flavonoids as anti-cancer agents: mechanisms of action and promise for their potential application in breast cancer. Bio- 
11. Nijveldt RJ, van Nood E, van Hoorn DE, Boelens PG, van Norren K, van Leeuwen PA. Flavonoids: a review of probable mechanisms of action and potential applications. Am J Clin Nutr. 2001; 74:418-425

12. Tsiri D, Graikou K, Poblocka-Olech L, Krauze-Baranowska M, Spyropoulos C, Chinou I. Chemosystematic value of the essential oil composition of Thuja species cultivated in Poland-antimicrobial activity. Molecules 2009; 14:4707-4715.

13. Naser B, Bodinet C, Tegtmeier M, Lindequist U. Thujaoccidentalis (Arbor vitae): A Review of its Pharmaceutical, Pharmacological and Clinical Properties. Evid. Based. Complement. Alternat. Med. 2005; 2:6978.

14. Mukherjee A, Sikdar S, Bishayee K, Boujedaini N, Khuda-Bukhsh AR. Flavonol isolated from ethanolic leaf extract of Thuja occidentalis arrests the cell cycle at G2-M and induces ROS-independent apoptosis in A549 cells, targeting nuclear DNA. Cell. Prolif. 2014 ; 47:56-71.

15. Mukherjee A, Sikdar S, Bishayee K, Paul A, Ghosh S, Boujedaini N, Khuda-Bukhsh AR. Ethanolic extract of Thujaoccidentalis blocks proliferation of A549 cells and induces apoptosis in vitro. Zhong Xi Yi Jie He Xue Bao. 2012; 10:1451-1459.

16. Roychoudhury S, Mondal NK, Mukherjee S, Dutta A, Siddique S, Ray MR. Activation of protein kinase B (PKB/Akt) and risk of lung cancer among rural women in India who cook with biomass fuel. Toxicol. Appl. Pharmacol. 2012; 259:45-53.

17. Zhao P, Fu J, Yao B, Song Y, Mi L, Li Z, Shang L, Hao W, Zhou Z. In vitro malignant transformation of human bronchial epithelial cells induced by benzo(a) pyrene. Toxicol. In Vitro. 2012; 26:362-368.

18. Dubey SK, Batra A. Antioxidant Activities of Thuja occidentalis Linn. Asian. J .Pharm. Clin. Res. 2009;
19. Olusola A, Olutayo O, Michael A, Olakunle F, Edah AO. Elemental analysis and Anti-microbial potentials of the leaf extract of Cassia arereh Del. Int. Res. J. Pharm. Pharmacol. 2011; 1:188-193.

20. Anandakumar P, Kamaraj S, Ramakrishnan G, Jagan S, Devaki T. Chemopreventive task of capsaicin against benzo(a)pyrene-induced lung cancer in Swiss albino mice. Basic. Clin. Pharmacol. Toxicol. 2009; 104:360-365.

21. Fuss IJ, Kanof ME, Smith PD, Zola H. Isolation of whole mononuclear cells from peripheral blood and cord blood. Curr. Protoc. Immunol. 2009; doi:10.1002/0471142735.im0701s85.

22. Chakraborty D, Mukherjee A, Sikdar S, Paul A, Ghosh S, Khuda-Bukhsh AR. [6]-Gingerol isolated from ginger attenuates sodium arsenite induced oxidative stress and plays a corrective role in improving insulin signaling in mice. Toxicol. Lett. 2012; 210: 34-43.

23. Rahman I, Kode A, Biswas SK. Assay for quantitative determination of glutathione and glutathione disulfide levels using enzymatic recycling method. Nat Protoc. 2006; 1:3159-3165.

24. Goh FY, Upton N, Guan S, Cheng C, Shanmugam MK, Sethi G, Leung BP. Wong WS. Fisetin, a bioactive flavonol, attenuates allergic airway inflammation through negative regulation of NF-KB. Eur. J. Pharmacol. 2012; 679:109-116.

25. Kundu S, Sengupta S, Chatterjee S, Mitra S, Bhattacharyya A. Cadmium induces lung inflammation independent of lung cell proliferation: a molecular approach. J. Inflamm. (Lond). 2009; 6:19.

26. Efferth T, Giaisi M, Merling A, Krammer PH, Li-Weber M. Artesunate induces ROS-mediated apoptosis in doxorubicin-resistant T leukemia cells. PLoS One. 2007; 2:e693. 
27. Liu C, Liu H, Li Y, Wu Z, Zhu Y, Wang T, Gao AC, Chen J, Zhou Q. Intracellular glutathione content influences the sensitivity of lung cancer cell lines to methylseleninic acid. Mol. Carcinog. 2001; 51:303-314.

28. Sarkar M, Chaudhuri K. Association of adherence and motility in interleukin 8 induction in human intestinal epithelial cells by Vibrio cholerae. Microbes. Infect. $2004 ; 6: 676-685$.

29. Schneider CA, Rasbandws Eliceiri KW. NIH Image to ImageJ: 25 years of image analysis. Nature Methods. 2012; 9:671-675.

30. Ganguly A, Basu S, Chakraborty P, Chatterjee S, Sarkar A, Chatterjee M, Choudhuri SK. Targeting mitochondrial cell death pathway to overcome drug resistance with a newly developed iron chelate. PLoS One. 2010; 5:e11253.

31. Benzie IF, Szeto YT, Strain JJ, Tomlinson B. Consumption of green tea causes rapid increase in plasma antioxidant power in humans. Nutr. Cancer. 1999; 34:3-7.

32. Tietze F. Enzymic method for quantitative determination of nanogram amounts of total and oxidized glutathione: applications to mammalian blood and other tissues. Anal. Biochem. 1969; 27:502-522.

33. Weydert CJ, Cullen JJ. Measurement of superoxide dismutase, catalase and glutathione peroxidase in cultured cells and tissue. Nat. Protoc.2010; 5:51-66.

34. Sambrook J, Russell DW. Molecular Cloning, Cold Spring Harbor Laboratory Press, 2001; New York. 3rd ed.

35. Tsuji G, Takahara M, Uchi H, Takeuchi S, Mitoma C, Moroi Y, Furue M. An environmental contaminant, benzo(a)pyrene, induces oxidative stress-mediated interleukin-8 production in human keratinocytes via the aryl hydrocarbon receptor signaling pathway. J. Dermatol. Sci. 2011; 62:42-49.
36. Wu H, Che X, Zheng Q, Wu A, Pan K, Shao A, Wu Q, Zhang J, Hong Y. Caspases: a molecular switch node in the crosstalk between autophagy and apoptosis. Int J Biol Sci. 2014; 10:1072-1083.

37. Xu N, Lao Y, Zhang Y, Gillespie DA. Akt: a double-edged sword in cell proliferation and genome stability. J. Oncol. 2012; doi: 10.1155/2012/951724.

38. Chin YR, Toker A. Function of Akt/PKB signaling to cell motility, invasion and the tumorstroma in cancer. Cell Signal. 2009; 21:470-476.

39. Fresno Vara JA, Casado E, de Castro J, Cejas P, Belda-Iniesta C, González-Barón M. PI3K/Aktsignalling pathway and cancer. Cancer Treat. Rev. 2004; 30:193-204.

40. Reagan-Shaw S, Nihal M, Ahmad N. Dose translation from animal to human studies revisited. FASEB. J. 2008; 22:659-661.

41. Gong T, Wang CF, Yuan JR, Li Y, Gu JF, Zhao BJ, Zhang L, Jia XB, Feng L, Liu SL. Inhibition of Tumor Growth and Immunomodulatory Effects of Flavonoids and Scutebarbatines of Scutellaria barbata D. Don in Lewis-Bearing C57BL/6 Mice. Evid Based Complement Alternat Med. 2015; 2015:630760

42. Devadoss D, Ramar M, Chinnasamy A. Galangin, a dietary flavonol inhibits tumor initiation during experimental pulmonary tumorigenesis by modulating xenobiotic enzymes and antioxidant status. Arch Pharm Res 2014; 1-11.

43. Ren W, Qiao Z, Wang H, Zhu L, Zhang L. Flavonoids: promising anticancer agents. Med Res Rev 2003; 23:519-534.

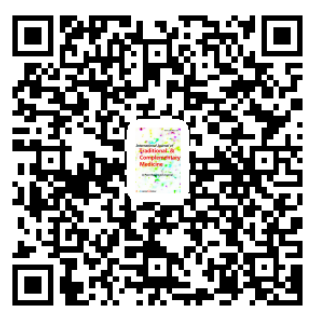

